\title{
Arundhati Roy's The God of Small Things: Traumatic Distress in Children
}

\section{Pradeep Kumar Giri}

Associate Professor of English, Head (English Department); Tri-Chandra Multiple Campus, TU, Kathmandu, Nepal

\begin{abstract}
Arundhati Roy's novel The God of Small Things (1997) narrates trauma and its deep distress in child psychology. The novel consists of multiple traumas. Rahel and Estha-- the two major characters - are haunted by past events throughout their life. I pay particular attention to child psychology affected by trauma, its causes, symptoms and responses are examined in relation to the experience of the children particularly Rahel and Estha. In this article I employ the theoretical frameworks of psychological trauma studies in relation to childhood. It provides interpretations of psychological trauma in the childhood and its long-lasting affects even in the adult life. The protagonists are two twin children Rahel and Esthappen.
\end{abstract}

Keywords - trauma, psychology, humiliation, trigger, nightmares.

\section{OVERVIEW OF TRAUMA THEORY}

The Greek word "trauma" or "wound" originally refers to an injury taken place on a body. But in the medical and psychiatric literature and most generally in Freud's text, trauma is understood as a wound laidupon the mind.In Unclaimed Experience: Trauma, Narrative and History, Cathy Caruth calls trauma "double wound," an event which is not available to consciousness until it imposes itself again, repeatedly, in the nightmares and repetitive actions of the survivor. It cannot be linked only to what is known, but also to what remains unknown in our actions and our language $(3,1996)$. Unlike physical wound, it is not available to consciousness until it imposes itself again, repeatedly in the nightmares and repetitive actions of the survivor (Schonfeldar3). In the beginning, situated in the domain of medicine and then psychology, the study of trauma has, over the last few decades, become "relevant in literary and cultural studies" (28).In Unclaimed Experience: Trauma and the Possibility of History, Cathy Caruth defines trauma as:

... a phenomenon that not only arises in the reading of literary or philosophical texts but emerges most prominently within the wider historical and political realms, that is, the peculiar and paradoxical experience of trauma. In its most general definition, trauma describes an overwhelming experience of sudden or catastrophic events in which the response to the event occurs in the often delayed, uncontrolled repetitive appearance of the hallucinations and other intrusive phenomenon. $(11,1991)$

Cathy focuses on the response to the overwhelming, experience and is often delayed. The response is uncontrolled, repetitive hallucinations and other intrusive phenomenon. In Psychology of Trauma Simon BN Thompson states:

. . . in psychology, trauma means an emotional or psychological Scon sequence of a stressful or even life threatening event. An individual's reaction to a traumatic event depends on many factors involving perception of threat to life, personality, current life status (health, well-being and emotional stability), occupational status, family support structure and coping strategies. (17)

Cathy Caruth, in Trauma: Explorations in Memory asserts that fields like psychiatry, psychoanalysis and neurobiology suggest its importance. It is a history that literally has no place, neither in the past, in which it was not fully experienced, nor in the present, in which its precise images and its effect are not fully understood (153). Freud in Moses and Monotheism as (qtd. in Berger570) attempts a theory of trauma that would account for the historical development of entire cultures. Julia Tanney in her book, Trauma and Belief, writes that when we undergo a traumatic experience, such as life-threatening accident or brutal attack, war or witness or commit atrocities, we survive a period of relentless stress. The other reasons may be raised by parents who are alcoholic or mentally ill or we 
are ignored and neglected. About memory, she opines that a person is usually considered authoritative about what she remembers, but the justification (or criterion) for the application of the concept of memory in those circumstances is the unusual behavior of one who has traumatized (352). Dominic LaCapra, in his article, "Trauma, Absence and Loss," puts his views on trauma, absence and loss. "Loss" is often correlated with "lack," for as loss is to the past. "Lack" is to the present and future (703) whereas "absence" is the absence of an absolute (702). Judith Greenberg in her article, "The Echo of Trauma and the Trauma of Echo" talks about the "rememories," paradoxical situations in which the event is inaccessible at the moment of its occurrences and then possesses the survivors after a gap in time. . . . It hovers outside of one particular of moment, reassembling or confusing the boundaries of time (32).Karyan Freedman in her article "Akratic Believing, Psychological Trauma and Somatic Representations"offers key insight into the ways that individuals process and store traumatic experiences. The traumatic stress has a profound impact on sensorimotor reactions. The traumatic stress affects biological responses to threat the flight or fight mechanism- is halted, the nervous system becomes overwhelmed. Then, the neurobiological systems, is physiologically deregulated, which has a profound impact on our ability to regulate affect (emotional responses to situations). This inability to regulate our emotional responses and impulses becomes dispositional and those dispositions effectively trump higher cognitive processing.

\section{CRITICAL OVERVIEW OF THE GOD OF SMALL THINGS}

The setting of the novel is in India - Kerala. The novel begins with Rahel's returning from America. She comes in Ayemenem in Kerala to meet her brother Estha after having been separated for 23 years. Estha is also "rereturned" by his father in Calcutta. The twins cannot live a normal childhood life like other children astheir whole lifetime move around the traumatic events. The plot of the novel moves back and forth as they have flashbacks of past events. Pappachi, the famous scientist, always has a gloomy mood and beats his wife and daughter. Therefore, his daughter Ammu goes for an inter-communal love marriage to come out of violence at home. Bad luck to her, her husband turns out to be an alcoholic man. He tortures her. Ammu divorces him and goes to her parental home for shelter with her children Rahel and Estha. There, they are treated like unwanted guest. Other children insult them for being the children of divorced parents. As there is not peace and harmony in the family Ammu is in angry mood. ISSN: 2456-7620
Estha and Rahelbecome victim of their mother's anger and dissatisfaction. Their survival is threatened with bullying of grownups. Rahel develops nervousness. She feels Pappachi's moth fluttering in her heart. The children witness the violence and torture by Pappachi to Mamachi. They are indulged to face a number of violence and stressful events.

Hope Jennings observes the presence of nostalgia in her article "The Ethics of Nostalgia in Arundhati Roy's 'The God of Small Things." She points out how the children had suffered from the past. She mentions:

Rahel and Estha are perpetually living
with the ghosts of the past and due to the
nature of their trauma, time for them has
become frozen like Rahel's toy watch
with the hands pointed out it at ten to
two. This is symbolic itself in spite of the
text's fluid narrative movements between
past and present... (132)

Jennings says that the novel is a retracing of the traumatic loss and displacement. The twins, Rahel and Estha experience due to the loss of their mother and each other (190).She notices "Pappachi's moth" will flutter and beat into Rahel's chest whenever she feels threatened (183).

Loveleen Kaur in "The Right of Girl Child in Indian Society as Foregrounded by Arundhati Roy in 'The God of Small Things" interprets the work of Roy from the point of view of girl child rights. She analyzes various negligence and discrimination against children, particularly girl child and shocking effects of patriarchy on children. She views that the novel exposes the abuse, exploitation and neglect of girl child and her rights in Indian society and towards life (43). She mentions that Roy presents the three generations of girl child suffer neglect and discrimination in Indian patriarchal society (46). She notices how Rahel undergoes humiliation and marginalization in orthodox society for being a daughter of divorced parents from inter-communal love marriage. Her being a female deprives Rahel of love and affection that are necessary for the healthy growth of any child. After her mother's death, she leads an isolated life and exposure to cruelties at tender age affects her psyche badly. By birth, she is in position of weakness (52).Kaur opines that Rahel is always compared with her cousin Sophie Mol and Rahel is neglected and considered inferior to Sophie. Sophie Mol has privilege over Rahel for being daughter of a member of ruling class, though both are daughters of divorced parents. She points out the reason of strange behavior of Rahel is her separation from her mother and brother. This separation has disastrous affect which left her feelings of 
being alone, blankness sand incompleteness in her (52).In the personal development, emotional development, and social life the events badly affect to the children which Roy discusses in the novel. They have been victims of past memories of series of deaths, violence, enforced separation, bullying, neglect, humiliation, and stressful times. Their life cannot move forward smoothly as other children's due to the traumatic events occurred at the age of seven. This article attempts to analyze the "nightmares" and "intrusive flashbacks" which led their life backward.

L. Chris Fox discussion on the relation of distress and trauma in "The God of Small Things in a Martyrology of the Abject: Witnessing and Trauma in Aruadhati Roy's 'The God of Small Things,"' gives a good picture of how distress plays the most vital role in making a child traumatized. She opines, "the abject is everything that human body excretes in order to live all that might endanger our lives should we touch ingest it, it is the things we must not do in order to be proper subject in our societies (36)." She finds misery experience provided that the degree is dependent on personal and social context. She explores thatThe God of Small Things is a novel of multiple traumas which are which are the products of the experiences of the abject which are forced upon several of the least powerful member of the society (38). The traumatic structure of the narrative forces readers to experience the trauma of the abject as they are already subject to it (34). . . . Traumatic memory patterns inspire not only the content but also the narrative structure. It seems to share the urgency to communicate, a problem of repression which implies a desire for social healing, figured perhaps in the (re) union of Estha and Rahel (56)."

The twin Estha and Rahel are victims of domestic violence at their father's home and wherever they go as they did not have any one to love them truly but thrown in the world of hatred, misbehave, and exploitation. Pappachi, their maternal grandfather, is always in "black mood" (49). There is always dispute and argument in the family. The home environment is always stressful.They are not handled with care and sensitivity. They see their parents fighting all the time; their alcoholic Baba and Ammu - they divorce.The home atmosphere filled with physical abuse, violence and torture filled their tender mind with psychological wound. Twenty-three years later, Rahel finds a notebook of Estha. In the handwriting hisdisturbed personality could be seen. He is severely affected by the events that took place in his life.

'The labored form of each letter and the irregular space between words was full of struggle for control over the errant, self-willed pencil. The sentiment in contrast was lucid: I Hate Miss Mitten and I think the gnickers are torn.

On the front of the book, Estha had robbed out his surname with spit and ... he had written in pencil unknown. Esthappen un-known. (156)

In her article "The Theme of Agonized Childhood in 'God of Small Things and the White Tiger,"” Monika Agrawal attempts to discover how the qualities of childhood is blocked. She views that the word childhood, its related ideas and events happen over and over to reflect the agonized childhood as the fundamental theme (353). The dreadful accidents leave everlasting scars on the mind in the childhood from where fear perpetually emerges in their life. The children want to be 'loved,' 'valued' and 'needed' (232). If they are bullied, blackmailed emotionally, isolated, and behaved trickily by grownups they get psychologically traumatized. They have been subjected to" psychological trauma that leaves deep unhealable scars on their bodies" (354).

The twins who are totally interdependent to each other are forced to be separated from each other and from their mother, which is a big shock to them. Estha quits his education after school. He stops talking and just keeps on walking. After some time, he re-returns to Ayemenem as an object. Ammu dies alone at the early age in a pitiful condition. Little Rahel faces the untimely death of her mother alone without Estha. Then, she becomes abnormal. She divorces; after the separation of twenty-three years, they re-unite. As the memories of tragic moments trouble them they feel that they are the helpless and victims even in the adulthood. They cannot live their life at present moment. Having suffered the traumatic events one after another, the two twin react to it in their own way.

\section{CONCLUSION}

To conclude, the whole life of Estha and Rahel moves around their traumatized childhood. Both of them face dreadful, overwhelming and stressful events in their childhood days. The experience of a chain of traumatic incidents such as untimely death of loved ones, violent scenes, abuse, insult, humiliation and enforced separation make them trauma survivors. The traumatic distress in his life Estha gets strangely quiet and his sister Rahel becomes totally empty and emotionless. The series of traumatic incident triggers their memory throughout their life. The plot moves back and forth as the twin have disturbing memory and recollections of the traumatic events taken place in their childhood days. They find nobody to care about their feelings; they are dejected of care, protection 
and attention of the elder. Even from their mother they get threatening to do as she says. The twins who are totally dependent to each other are forcefully separated. The main focus of this article is to deal with the effects of trauma in child psychology and their response to it. One trauma initiates memory of another trauma. They live their past in present life too which make them feel worrying till the last moment of their life. As her own family members, relatives and friends always ignore and even hate her Rahel gets affected from her childhood to womanhood. Her past memories follow her and haunt. Therefore, she could not live present life as other people do. Her husband does not understand that. Frequent panic attack from her husband makes her feel that there was no one is this world who would understand her real situation. She does not have any kind of emotion left inside. Even her husband cannot understand her psychological condition. As a result, he divorces her. The whole devastating incident victimizes her. Estha's withdraw himself socially and Rahel's turning into emotionless and ambitionless person is a powerful portrayal of traumatic distress in children.

\section{REFERENCES}

[1] Agrawal, Monika. "The Theme of Agonized Childhood in "The God of Small Things and the White Tiger."' IMPACT: International Journal of Research in Humanities, Arts and Literature, vol.6, no.5, 2018.

[2] Berger, James. "Trauma and Literary Theory." Contemporary Literature, vol. 38 no. 3, University of $\begin{array}{llll}\text { Wisconsin Press. } & \text { Autumn, }\end{array}$ <https://www.jstor.org/stable/208980>

[3] Caruth, Cathy, editor. Trauma: Explorations in Memory. Johns Hopkins University Press, 1995.

[4] - - . Unclaimed Experience: Trauma, Narrative and History. Johns Hopkins University Press, 1996.

[5] - - . Unclaimed Experience: Trauma and the Possibility of History. Yale University Press, 1991. https://www.jstor-org /stable/2930251.

[6] Fox, L. Chris. "A Martyrology of the Abject: Witnessing and Trauma in Arundhati Roy's 'The God of Small Things."” ARIEL, vol. 33, no. 3-4, 2002.

[7] Greenberg, Judith. "The Echo of Trauma and the Trauma of Echo.” American Imago, vol. 55, no. 3, Fall, Johns Hopkins University Press, 1998.< https://www.jstor.org/stable/j.ctv1wxrhq.5>

[8] Jennings, Hope. "The Ethics of Nostalgia in Arundhati Roy's 'The God of Small Things." Journal of Contemporary $\begin{array}{lllll}\text { literature, } & \text { vol. } & 2, & \text { no. } & 1,\end{array}$ <https://corescholor.libraries.wright.edu/english/2004>

[9] Kaur, Loveleen. "The Rights of Girl Child in Indian Society as Foregrounded by Arundhati Roy in 'The God of Small Things."'International Journal of English Language, Literature andHumanities, vol. 2, no. 2, 2014.
[10] LaCapra, Dominic. "Trauma, Absence and Loss." Critical Inquiry, vol. 25, no. 4, Summer, 1999. pp.702-725.URL: https:// www.jstor.org / stable / 1344100

[11] Schonfelder, Christina. Woundsand Words: Childhood and Family Trauma inRomantic and Postmodern Fiction. Transcript Verlag, 2013.

[12] Tanney, Julia."Trauma and Belief."Philosophy, Psychiatry and Psychology, vol. 24, no. 4, 2017.

[13] Thompsen, BN Simon.Psychology of Trauma. Oxford Press, 2013. 